\title{
ANALISIS PENDAPATAN USAHA ROTI PADA INDUSTRI RUMAH TANGGA FARIDA BAKERY DI DESA CIKUNIR KECAMATAN SINGAPARNA KABUPATEN TASIKMALAYA
}

\author{
ITMAM JAUHARUL HUDA ${ }^{*}$, DINI ROCHDIANI ${ }^{2}$, AGUS YUNIAWAN ISYANTO ${ }^{1}$ \\ ${ }^{1}$ Fakultas Pertanian, Universitas Galuh Ciamis \\ ${ }^{2}$ Fakultas Pertanian Universitas Padjajaran \\ *Email: itmamjauhar@gmail.com
}

\begin{abstract}
ABSTRAK
Farida Bakery merupakan salah satu industri roti yang tergolong dalam industri rumah tangga. Tujuan keseluruhan aktifitas Farida Bakery adalah untuk memperoleh pendapatan yang tinggi. Besarnya biaya bahan baku pembuatan roti mempengaruhi pendapatan yang diperoleh Farida Bakery dan saat ini dari usaha roti ini belum memberikan pendapatan sesuai dengan yang diharapkan. Penelitian ini bertujuan untuk mengetahui besarnya biaya, penerimaan dan pendapatan serta Imbangan antara penerimaan (revenue) dan biaya (cost) pada usaha roti pada industri rumah tangga Farida Bakery. Metode penelitian yang digunakan adalah studi kasus, lokasi ditentukan secara purposive sampling dengan pertimbangan bahwa bisnis ini berada di Desa Cikunir Tasikmalaya yang merupakan home industri. Konsep biaya produksi yang digunakan adalah konsep biaya produksi yang terdiri dari biaya bahan baku langsung (BBL), biaya tenaga kerja langsung (BTKL) dan biaya overhead pabrik (BOP). Hasil penelitian menunjukkan bahwa biaya produksi sebesar Rp. 1.977.285,39. Penerimaan yang diperoleh usaha roti sebesar Rp. 2.850.000,00. Pendapatan yang diperoleh usaha roti Rp. 872.714,61. Imbangan antara penerimaan (revenue) dan biaya (cost) pada usaha roti dengan $\mathrm{RC}: 1.44$

Kata Kunci : Analisis Pendapatan, Agribisnis, Industri rumah tangga
\end{abstract}

\begin{abstract}
Farida Bakery is a bakery industry that is classified as a home industry. The overall objective of Farida Bakery activities is to obtain high income. The amount of raw material costs for making bread affects the income earned by Farida Bakery and currently the bread business has not provided income as expected. This study aims to determine the amount of costs, revenues and revenues as well as the balance between revenue and costs in the bread business in the home industry of Farida Bakery. The research method used is a case study, the location is determined by purposive sampling with the consideration that this business is located in the village of Cikunir Tasikmalaya which is a home industry. The concept of production costs used is the concept of production costs consisting of direct raw material costs $(B B L)$, direct labor costs $(B T K L)$ and factory overhead costs $(B O P)$. The results showed that the production cost was Rp. 1,977,285.39. The revenue earned by the bread business is Rp. 2.850.000,00. The income earned by the bread business is Rp. 872.714,61. Balance between revenue and cost in a bread business with $R C: 1.44$
\end{abstract}

Keywords: Income Analysis, Agribusiness, Home industry

\section{PENDAHULUAN}

Industri makanan dan minuman merupakan penopang pertumbuhan ekonomi Indonesia, sehingga peranannya masih perlu ditingkatkan dalam membantu pertumbuhan ekonomi dengan cara melihat masalah apa saja yang sedang dihadapi oleh pemilik industri makanan dan minuman yang ada di Indonesia. Seiring perkembangan bisnis yang disertai persaingan yang begitu ketat, menimbulkan beberapa masalah 
diantaranya keterbatasan sumber daya yang digunakan yang menyebabkan pelaku industri kecil berusaha keras untuk bertahan dalam persaingan pasar. Untuk mengatasi hal seperti ini pemilik usaha harus mampu memanfaatkan sumber daya yang ada secara efektif dan efesien dalam mencapai keuntungan maksimal (Firdaus, 2007).

Peranan industri makanan dan minuman ini dapat dilihat dengan banyaknya industri yang berkembang baik industri yang berskala kecil maupun berskala besar. Salah satu industri makanan yang tetap ramai dan berkembang sampai saat ini adalah industri makanan roti. Gaya hidup masyarakat yang lebih memilih makanan instan menyebabkan roti banyak digemari oleh konsumen. Roti adalah produk makanan olahan yang merupakan hasil proses pemanggangan adonan yang telah difermentasi. Bahan utama dalam pembuatan roti terdiri atas tepung, air, ragi, gula, mentega dan garam, jenis roti-roti yang diproduksi di perusahaan tergantung pada rasa, antara lain rasa coklat, keju, pisang, dan coklat kacang (Adisarwanto, 2017)

Usaha roti diberbagai daerah umumnya dikelola oleh industri rumah tangga (home industry). Home industry adalah perusahaan yang masih menggunakan tenaga rumahan tetapi mempunyai keuletan tersendiri untuk tetap bertahan di pasaran. Semua pebisnis yang tidak memiliki modal besar pasti mengalami pekerjaan sebagai home industry, dimana untuk bisa bersaing dengan perusahaan besar maka ia harus benar-benar memutar otak, membuat konsep yang menarik, dan dituntut untuk senantiasa kreatif dengan sumberdaya seadanya.

Industri rumah tangga adalah rumah usaha produk barang atau juga perusahaan kecil. Dikatakan sebagai perusahaan kecil karena jenis kegiatan ekonomi ini dipusatkan di rumah. Industri rumah tangga (home industry) diharapkan dapat meningkatkan nilai ekonomi dan pendapatan pelaku industri rumah tangga. Pengembangan bisnis kecil dapat meningkatkan pertumbuhan dan mengubah struktur ekonomi nasional menjadi lebih kokoh dan berimbang. Hasil ini diperoleh karena masyarakat berperan aktif dalam pengembangan usaha nasional yang didukung oleh kebijaksanaan yangl ebih kondusif (Arumdyan, 2011).

Usaha dalam bidang kuliner seperti produksi roti dan kue merupakan salah satu alternatif dalam usaha rumahan yang banyak dilakukan oleh masyarakat, oleh karena itu, usaha produksi roti dan kue 
memiliki masa depan yang baik karena roti dan kue banyak dikonumsi dan dibutuhkan oleh masyartakat. Untuk membangun sebuah pabrik roti kelas kecil (usaha rumah tangga) ada 4 poin penting yang harus dilakukan, yaitu penentuan jenis roti yang akan diproduksi, pembuatan tempat produksi yang memenuhi standar kesehatan, peralatan produksi higienis, dan jangkauan atau target pemasaran.

Industri tepung terigu tanah air semakin berprospek cerah, walaupun harga bahan baku terus mengalami kenaikan dimana pada bulan Maret tahun 2020 mencapai Rp. 37500, namun permintaan tetap mengalami pertumbuhan yang signifikan. Selama tahun 2019 permintaan tepung terigu naik sebesar $4 \%$ dari tahun sebelumnya. Hal ini di dorong semakin banyaknya bisnis kuliner seperti bakery dan UMKM yang membutuhkan bahan baku terigu. Namun, pada masa pandemi covid-19 telah memengaruhi permintaan tepung terigu secara nasional, pasar tepung terigu nasional tercatat turun dua persen. Terkait kenaikan harga bahan baku, yakni gandum, diprediksi kenaikan akan terus bertahan hingga enam bulan pertama di 2019 ini. hal ini diperberat dengan masa pandemi COVID19 yang dapat menghambat aktivitas ekonomi di pasaran (Wijaya, 2019).
Kenaikan harga bahan baku tepung terigu sangat mempengaruhi pendapatan perusahaan, maka dari itu perusahaan harus mempunyai strategi untuk mempertahankan konsistensinya dalam dunia bisinis dan tetap berjalan, misalnya adalah dengan memperkecil ukuran roti yang akan dibuat dengan tidak menaikkan harga roti tersebut. Selain itu, kenaikan harga bahan bakupun akan otomatis dapat mempengaruhi pada biaya produksi. Sehingga biaya yang dikeluarkan oleh suatu perusahaan akan menjadi patokan yang harus kembali bahkan memperoleh keuntungan, bila perusahaan tersebut memperoleh keuntungan, maka bisnis tersebut akan tetap berjalan.

Keberhasilan suatu perusahaan antara lain dapat diukur dari tingkat pendapatan yang diperoleh. Pendapatan adalah selisih antara penerimaan perusahaan dengan biaya yang dikeluarkan. Besarnya pendapatan yang diterima merupakan balas jasa untuk tenaga kerja dan modal yang dipakai dan pengelolaan dalam kegiatan produksi. Salah satu permasalahan dalam proses produksi adalah kurangnya bahan baku untuk menghasilkan suatu produksi (Umar, 2013).

Menurut Nurmalina et al. (2009), penilaian dalam studi kelayakan bisnis 
dilakukan secara menyeluruh dari berbagai aspek yaitu aspek non finansial yang meliputi: aspek pasar, teknis, manajemen dan hukum, sosial-ekonomi-budaya, lingkungan dan aspek finansial (keuangan). Beberapa aspek non finansial yang merupakan aspek dalam studi kelayakan bisnis dianalisis secara kualitatif dan tidak terkait dengan biaya dan manfaat yang bersifat kuantitatif.

Hasil penelitian yang dilakukan oleh Pribadi (2019) menggunakan analisis pendapatan, pendapatan total atau keuntungan yang diperoleh pada Industri Rumah Tangga “Aisyah Bakery” yaitu Rp 10.596.731 dimana total penerimaan $\mathrm{Rp}$ 35.100 .000 dikurangi dengan total biaya Rp 24.503.269; sehingga pendapatan usaha roti yaitu $\mathrm{Rp} 10.596 .731$

Salah satu industri roti yang ada di Kabupaten Tasikmalaya yaitu industri Farida Bakery yang terletak di Kecamatan Singaparna Kabupaten Tasikmalaya. Industri rumah tangga Farida Bakery merupakan industri yang kapasitas menengah dengan kapasitas satu kali produksi membutuhkan $25 \mathrm{~kg}$ terpung terigu untuk ukuran sedang dan ukuran besar.

Produksi roti rutin dilakukan setiap hari, atau lebih tergantung dari adanya pesanan dengan memperkerjakan sekitar
15 orang karyawan. Menurut informasi yang diperoleh, biaya upah yang dikeluarkan untuk sekali produksi mencapai Rp 750,000. Sistem upah karyawan dengan menggunakan sistem borongan yang terdiri atas $\mathrm{Rp}$ 450.000/karung bagian produksi dan $\mathrm{Rp}$ 300.000 /karung bagian pengemasan (packing).

Bahan pokok yang digunakan oleh pabrik roti Farida Bakery diantaranya adalah tepung terigu, telur, margarin, gula, coklat, bos, sp, garam, telur, kalsium, susu bubuk, maolipan agar kelembutan adonan roti tersebut halus ketika sedang membuat adonan roti. Kendala yang dihadapi Farida Bakery adalah fluktuasi harga dari bahan baku (tepung terigu, telor coklat bubuk, dan gula pasir) yang digunakan dalam proses produksi serta keterbatasan tenaga kerja.

Farida Bakery merupakan salah satu industri roti yang tergolong dalam industri rumah tangga. Tujuan keseluruhan aktifitas Farida Bakery adalah untuk memperoleh pendapatan yang tinggi. Besarnya biaya bahan baku pembuatan roti mempengaruhi pendapatan yang diperoleh Farida Bakery dan saat ini dari usaha roti ini belum memberikan pendapatan sesuai dengan yang diharapkan. 
Tabel 2. Penerimaan Farida bakery

\begin{tabular}{|c|c|c|c|c|}
\hline Penerimaan & Satuan & Jumlah & Harga & Jumlah \\
\hline Roti Kecil & Pcs & 700 & $1.500,00$ & $1.050 .000,00$ \\
\hline \multirow[t]{2}{*}{ Roti besar } & Pcs & 400 & $4.500,00$ & $1.800 .000,00$ \\
\hline & & & & $2.850 .000,00$ \\
\hline
\end{tabular}

\section{Pendapatan}

Pendapatan yang diperoleh dari usaha roti Farida bakery ini merupakan selisih antara penerimaan dengan biaya total yang dihitung per produksi

Tabel 3. Pendapatan Farida bakery

\begin{tabular}{|l|l|r|}
\hline No & Variabel & Rp. \\
\hline 1 & Penerimaan & 2.850 .000 \\
\hline 2 & Biaya total & 1.977 .285 \\
\hline \multicolumn{2}{|r|}{ Pendapatan } & $\mathbf{8 7 2 . 7 1 4 , 6 1}$ \\
\hline \multicolumn{2}{|r|}{ Data pada tabel diatas }
\end{tabular}

menunjukkan bahwa dengan keuntungan sebesar Rp. 872.714,61 yang diperoleh dari perhitungan penerimaan sebesar Rp. 2.850.000 dikurangi biaya total produksi sebesar Rp. 1.977.285,39

\section{RC Ratio}

Hasil perhitungan dan analisis data yang dilakukan maka dapat diperoleh bahwa analisis kelayakan rata-rata R/C ratio dari Farida Bakery adalah sebesar 1.441 untuk lebih jelasnya dapat dilihat pada tabel berikut:
Tabel 4. RC Ratio Farida Bakery

\begin{tabular}{|l|l|r|}
\hline No & Variabel & Rp. \\
\hline 1 & Penerimaan & $2.850 .000,00$ \\
\hline 2 & Biaya total & 1.977 .285 \\
\hline RC & & $\mathbf{1 . 4 4}$ \\
\hline
\end{tabular}

Data pada tabel diatas menunjukkan bahwa nilai RC sebesar 1.44 artinya usaha tersebut layak diusahakan, karena nilai R/C lebih dari satu. Dengan melihat RC tersebut, perusahaan mampu memperoleh keuntungan. Jika dihitung dengan patokan nilai 1 , sedangkan revenue sebesar 1,44 maka perusahaan memiliki kelebihan sebesar 0,44. Nilai RC tersebut diperoleh dengan cara pembagian penerimaan sebesar Rp. 2.850.000,00 dibagi dengan biaya produksi sebesar $\mathrm{Rp}$. 1.977.285 maka diperoleh nilai $\mathrm{R} / \mathrm{C}$ sebesar 1.44.

Melihat dari data tersebut, pengusaha Farida Bakery layak untuk diusahakan. Hal ini disebabkan karena pada kondisi nyata banyak biaya yang riil dikeluarkan oleh pengusaha Farida Bakery seperti biaya bahan baku langsung (BBL), 
biaya tenaga kerja langsung (BTKL) dan biaya overhead pabrik (BOP). Biaya-biaya tersebut hanya sebagai imbalan atau ganti rugi atas penggunaan input (modal). Selain itu pengusaha Farida Bakery mendapatkan hasil dari usaha tersebut telah mampu menambah penghasilan.

\section{KESIMPULAN}

Berdasarkan hasil penelitian yang telah dilakukan maka dapat disimpulkan sebagai berikut:

1. Biaya produksi sebesar roti pada industri rumah tangga Farida Bakery Rp. $\quad 1.977 .285,39$. Penerimaan yang diperoleh Rp. 2.850.000,00 dan Pendapatan yang Rp. 872.714,61

2. Imbangan antara penerimaan (revenue) dan biaya (cost) pada usaha roti pada industri rumah tangga Farida Bakery di Desa Cikunir Kecamatan Singaparna Kabupaten Tasikmalaya dengan RC : 1.44

\section{SARAN}

Berdasarkan hasil penelitian yang dilaksanakan maka disarankan :

1. Sebaiknya pihak perusahaan dapat meningkatkan keuntungan pada usaha yang lebih besar dengan memanfaatkan analisis biaya produksi.

2. Sebaiknya pihak perusahaan dapat meningkatkan efisiensi usaha dengan cara mengefektifkan waktu produksi sehingga dapat menekan biaya-biaya operasional.

\section{DAFTAR PUSTAKA}

Adisarwanto, (2017). Proses Adonan dan Fermentasi.Jakarta: Penebar Swadaya.

Bustami (2009), Akuntansi Biaya. Edisi Pertama. Jakarta: Penerbit Mitra Wacana Media.

Firdaus, (2007). Manajemen Agribisnis. Jakarta: PT. Bumi Aksara.

Ibrahim (2003), Perencanaan Pengajaran. Bandung: PT. Remaja Rosdakarya.

Mamondol, Marianne Reynelda dan Ferdinan Sabe. 2016. Pengaruh Luas Lahan Terhadap Penerimaan, Biaya Produksi, dan Pendapatan Usahatani Padi Sawah di Desa Toinasa Kecamatan Pamona Barat. Dalam Jurnal Envira Vol. 1 No.2

Matz dan Matz, (2018). Cookies and Crackers Technology. West Port Connecticut: The AVI Publishing Co. Inc.

Moehar (2003), Metode Penelitian Sosial Ekonomi. Dilengkapi beberapa Alat Analisa dan Penuntun Penggunaannya. Jakarta: Penerbit PT.Bumi Aksara.

Mubyarto (2017). Pengantar Ekonomi Pertanian. Jakarta: LP3ES.

Mulyadi (2009). Akuntansi Biaya. Yogjakarta: UPP STIM YKPN.

Mursyidi (2008), Akuntansi Biaya. Cetakan Pertama. Bandung: Penerbit: Refika Aditama. 
Nurmalina, R., T. Sarianti dan A. Karyadi. 2009. Studi Kelayakan Bisnis. Bogor: Departemen Agribisnis. Fakultas Ekonomi dan Manajemen. Institut Pertanian Bogor

Siregar et al. (2013). Akuntansi Biaya. Edisi kedua. Jakarta: Salemba Empat.

Smith, (2012). Biscuit, Crakers and Cookies. Applied Science Publisher Ltd, London.

Soekartawi, 2002. Analisis Usahatani. UIPress. Jakarta.

Soekartawi, 2005. Analisis Teori dan Aplikasinya. Raja Grafindo: Yogyakarta.

Soekartawi, 2006. Agribisnis Teori dan Aplikasinya. Rajawali Press. Jakarta.

Standar Nasional Indonesia. 2011. Syarat Mutu Biskuit SNI 2973:2011. Jakarta: Dewan Srandar Indonesi, Badan Standarisasi Nasional

Suastina dan Kayana, 2015. Susunan Rencana Usaha. Udayana Press. Bali.
Sukirno, (2005). Mikro Ekonomi. Teori Pengantar. Jakarta: Penerbit PT. Raja Grafindo Persada.

Sumaatmadja (2014). Manusia dalam Konteks Sosial, Budaya, dan Lingkungan Hidup. Bandung: Alfabeta.

Sunaryo, (2015). Pengolahan Produk Serealia dan Biji-bijian. Fakultas Teknologi Pertanian, Institut Pertanian Bogor. Bogor.

Sutrisno. 2000. Manajemen Keuangan. Ekonosia. Yogyakarta.

Suwarsono, (2017). Studi Kelayakan Bisnis. Jakarta: PT. Gramedia Pustaka Utama.

Syarifuddin A.K. 2005. Petunjuk Praktis Menghitung Keuntungan dan Pendapatan Usahatani. Unlam Banjarbaru. Lambung Mangkurat Press.

Umar, (2013). Studi Kelayakan Bisnis. Jakarta: Rajawali Press. 